\title{
The relationship between family adjustment and expatriate performance
}

\author{
D. Trompetter, M. Bussin* and R. Nienaber \\ University of Johannesburg, PO Box 524, Auckland Park, 2006, South Africa \\ *To whom all correspondence should be addressed \\ drbussin@mweb.co.za
}

\begin{abstract}
Following the global economic collapse, executives are significantly more demanding in understanding the Return on Investment of employee-related programmes including expatriate programmes. Expatriates are defined as employees who are recruited to provide a service in a country which is not the country of residence, typically for at least three years. Expatriate programmes carry high risk; even more so when the family accompanies the employee. The cost of an expatriate assignment is, on average, three times higher than that of a local; yet the failure rate is estimated to be up to $40 \%$. Despite the cost, expatriate resources are critical to embed culture, policies and transfer of skills to a host country environment.
\end{abstract}

\begin{abstract}
The objective of this study was to identify the relationship between the adjustments of the expatriate's family in the host country on the performance of expatriates. The study was conducted using a quantitative research approach. A convenience sample was used and 81 expatriates completed the questionnaire. The results confirmed home to work spillover and that expatriates would value more organisational support for families in the new location. The length of stay in the host location was linked to higher levels of performance - the longer the assignment, the better the performance levels of the expatriate. Human Resources Practitioners can develop support programmes to ensure that expatriates and families are equipped to enhance their adjustment period and consequently positively impact the expatriate's performance whilst on assignment.
\end{abstract}

\section{Introduction}

\section{Key focus of the study}

As organisations globalise, they continue to face the challenge of sourcing talent for their operations abroad. Organisations often require management from the home country or head office environment to represent the organisation in the new location (referred to as the host country) to ensure that the culture, ethos and governance of the main organisation are replicated in the new location (Srivastava \& Panday, 2012). As organisations seek opportunities to expand their business abroad using expatriates to represent the home company, every effort needs to be made to guarantee a high return on investment in these programmes (Employment Conditions Abroad, (ECA) International, 2010).

Despite the focus on reducing costs, and an assignment failure rate of up to $40 \%$ (Chiotis-Leskowich, 2009), companies continuously increase their expatriate numbers in buoyant and developing markets (ECA International, 2013). Long term expatriate assignments of between 12 and 48 months, typically involve relocating an entire family to a new location (Lee, 2007b; Wilkinson \& Singh, 2010), presenting significant challenges for family adjustment. It is posited that family adjustment plays an important role in the performance of an expatriate on assignment and as such, is important to global employers, both from a financial and non-financial perspective (Lee, 2007b).

\section{Trends from the research literature}

Expatriate failure is seen as the premature return to the home country or normal place of residence, resignation of expatriates and/or substandard levels of performance (Carson, 2008; Chiotis-Leskowich, 2009; Shi \& Wang, 2014). Family problems and spousal dissatisfaction are prominent causes for expatriate failure.

For expatriates and the accompanying family to adapt quickly, particularly in a foreign environment in terms of language, religion and values, they need to be adept in crosscultural adjustment (Black, 1990). Black (1990) proposes that cross cultural adjustment takes place at three levels namely general adjustment (adapting to different living conditions), interaction adjustment (engaging comfortable with the locals in the host country), and work adjustment (fitting into the local culture).

The Spillover theory describes a process whereby one domain such as family adjustment affects another domain e.g. expatriate performance (Byron, 2005). Spillover is bidirectional between work-family and family-work (Haar \& Bardoel, 2008), indicating that family circumstances impact on the work environment as much as the work environment impact on family circumstances.

Family issues are cited as the main reason for either declining an expatriate assignment, or the premature return of the expatriate, and therefore if organisations can provide adequate support to the accompanying family, the expatriate and the organisation will ultimately benefit from a successful 
assignment indicated by the full term having been served at optimal levels of performance (Lee, 2007b).

\section{Research objectives}

The main research objective is to identify the relationship between an expatriate's family's adjustment in the host country and the expatriate's performance. Secondary research objectives aim to establish the influence of home to work spillover on the expatriate's performance; and whether previous international assignments moderate the family's adjustment in subsequent assignments.

\section{Contribution to the area of mobility management}

Line managers, HR Business Partners and Mobility professionals are all concerned with increasing return on investments for expatriate assignments. Financial (e.g. costs) and non-financial risks (e.g. reputation, brand, talent management) associated with these assignments can be mitigated through preparatory programmes that equip the line manager, the expatriate and the accompanying family with the required skills to adjust quickly and effectively in the home country. There are however few programmes available for the accompanying family in particular and an investment in the development of these types of programmes are unlikely unless it can be proven that the programme will render a positive return. Understanding the impact of the family's adjustment on the performance of the expatriate will provide the necessary impetus to develop and implement programmes that will positively impact the success rate of expatriate assignments.

\section{Literature review}

\section{Factors contributing to a successful expatriate} adjustment

The following factors contribute to the successful adjustment of an expatriate:

a) Expatriates adjusting in the host country in terms of domestic living conditions, social adjustment and work adjustment (Black, 1990);

b) Expatriate selection includes a high level of technical competence where it is expected that skills are transferred (Lee, 2007a), sound emotional intelligence (Gabel-Shemueli \& Dolan, 2011), motivational cultural intelligence (CQ) (Templer, Tay \& Chandraskekar, 2006) and Behavioural cultural intelligence (Che Rose, Sri Ramalu, Uli \& Kumar, 2010); and

c) Organisational support both after and before the inception of the assignment (Andreason, 2003). Line managers play a pivotal role in the expatriate's ability to perform (Chew, 2004).

Careful expatriate selection is therefore critical, and consideration should be given to both the technical and nontechnical ability demonstrated by the expatriate.
In addition, accompanying spouses have a difficult role in adjusting, considering that they are required to leave their job or restructure their career to support the expatriate and accompanying children (Adler \& Gundersen, 2007). Studies on expatriate adjustment indicate that the most commonly stated reason for expatriate failure is family-related. Other reasons contributing to the premature return of the expatriate include the expatriate having difficulty to adjust on the different levels stated, lack of managerial competence or support, the job not meeting the expectations and host country nationals not accepting the expatriate in the working environment (Brookfield Global Relocation Services, 2011; Chepkong'a, 2012; ECA International, 2011; Fukuda \& Chu, 1994; Yuen, 2003).

The U-Curve adjustment theory (Black and Mendenhall, 1991) posits that the expatriate's relocation results in high levels of uncertainty as to what to expect of the host country.

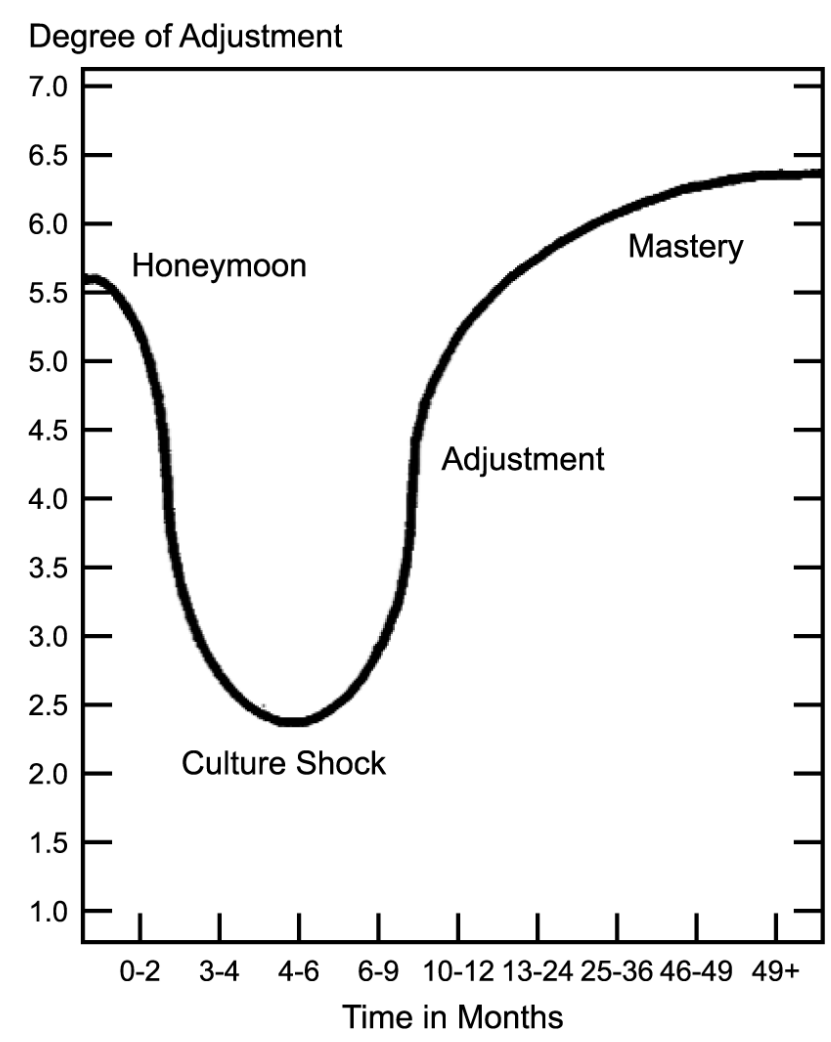

Figure 1: The U-curve of cross-cultural adjustment Black \& Mendenhall, 1991

As indicated in Figure 1, the adjustment of the expatriate and the accompanying family takes place over a period of time and comprises four phases, which include the initial period of assignment also termed the honeymoon phase, which is followed by culture shock, adjustment, and finally, the mastery phase. The honeymoon phase is characterised by feelings of excitement and curiosity which is quickly followed by feelings of frustration and disillusionment as the reality of the relocation sets in. During the third stage adaptation occurs and individuals learn how to behave in the new culture. The final stage, mastery, is where adjustment 
takes place on an incremental bases thereby improving functioning in the new culture.

Expatriates need to be made aware of these phases as part of the pre-departure preparation programmes to prepare them adequately for the emotions to be experienced. As the most common reason stated for expatriates to return home before the end of their contractual period, the expatriate family requires specific attention.

\section{The expatriate family}

It is estimated that at least $70 \%$ of expatriates are accompanied by a spouse with or without children (Van der Zee, Ali, \& Haaksma, 2007). Although it has been empirically confirmed that the expatriate family's ability to adjust has a significant impact on their ability to successfully complete an assignment in the host country (Palthe, 2008), there is paucity of research on understanding specifically the impact of the family's adjustment on the expatriate's performance. Various theories assist in describing the adjustment challenges that the family have to deal with.

\section{Family systems theory}

The family systems theory is based on the principle of viewing the family as an open system. According to Minuchin (1974), the family is an open socio-cultural system in transformation that continually undergoes development whilst moving through a number of restructuring phases; whilst the family members move through these phases psychological growth takes place with each of the family members. Therefore, if one family member is on an expatriate assignment which is a stressful event, it can affect the balance within the family system. In order to successfully transform through changing circumstances, the family has to function as a cohesive unit, supporting each other. Family cohesion is considered the strongest predictor in terms of quality of life and socio-cultural adjustment (Van Der Zee et al., 2007).

According to Olson (2000), the adjustment of the family accompanying the expatriate is dependent on the following characteristics: family cohesion (support), flexibility (adaptability) and communication. Flexibility is particularly important in the context of an international assignment where families are required to adapt to a number of changes i.e. child starting school, favourite snacks are no longer available, and extra-familial pressures i.e. the expatriate working long hours, lack of social support structures etc. Families who function well within the family system are able to accommodate to changes and adapt better in a foreign environment. Dysfunctional families will want to maintain the home country living conditions finding adjustment very difficult or even impossible. The final dimension in Olson's model namely communication, is described as the critical enabler for the other two dimensions cohesion and flexibility. Without these dimensions, the family is likely to experience high levels of stress and an inability to adjust effectively, supporting the Double ABCX theory.

\section{Double $A B C X$ theory}

In terms of the double ABCX theory, family stress is defined as the imbalance between demands and capabilities of a family. The demands referred to as the stressor or the A factor, and the family's capabilities to deal with such a stressor is termed the B factor. The C factor is the family's perception of the stressor. Where the family unit is unable to manage the stress using their capabilities and resources available a crisis occurs termed the $\mathrm{X}$ factor. Translated to an international assignment, where an expatriate family is faced with demands such as an international relocation (A), the family's internal resources (B) and their perception of the challenges linked to the relocation $(\mathrm{C})$ will interact to produce the family's adjustment $(\mathrm{X})$. According to the double ABCX theory, it is not so much the stressor that will influence the family's adjustment; rather, it is whether the family has the requisite coping capabilities and the ability to perceive the relocation challenges in a positive, adventurous light that will influence the family's ability to adjust to the new environment and thus directly contribute to the successful completion of the assignment. Having highlighted the family characteristics required to effectively work through transformation, the relationship between the family's ability to adjust and the expatriate's performance needs to be determined.

\section{Spillover theory}

Spillover is described as the transference of moods, skills, values and behaviors from one role to another (Carlson, Kacmar, Wayne \& Grzywacz, 2006). The relationship between work and family are interdependent with 'permeable' boundaries (Demerouti, Bakker, \& Tetrick, 2012). The Spillover theory illustrates the transfer of stressors emanating from one area to another. Spillover has been researched in different contexts for example the research by Takeuchi, Yun \& Tesluk (2002) found that expatriates' cultural adjustment spilled over to their work context and affect job satisfaction. Furthermore, an individual's functioning at work may have a positive or negative impact on their effective functioning within the family system. Similarly, one's functioning within the family system directly impacts, positively or negatively, the effective functioning within the work environment (Byron, 2005). Thus, Spillover is "an intra-individual contagion process that occurs across contexts", according Lazarova, Westman \& Shaffer (2010: 96).

Spillover has a bi-directional relationship whereby work influences family life, and family influences work life (Shimada, Shimazu, Bakker, Demerouti \& Kawakami, 2010). Spillover is relevant for this study as the experiences at home, may spillover to the performance levels at work and vice versa.

The literature review supports the importance of ensuring successful expatriate assignments for financial and nonfinancial reasons. The factors influencing the success of assignments are broad and diverse which place the emphasis 
on ensuring that the appropriate employee and accompanying family members are selected; not just the employee as so often happens. The expatriate and the accompanying family's ability to effectively adjust in the host location play an important role in the successful completion of the assignment. However, research not yet undertaken by scholars is to obtain empirical evidence of the impact of the family's adjustment, on the expatriate's level of performance within the working environment.

\section{Research design}

\section{Research approach}

A quantitative relational exploratory research design was adopted where the family's adjustment and the expatriate's performance levels were assessed from the perspective of the expatriate. The dependant variable is the expatriate's performance and the independent variables are the adjustment dimensions. Family adjustment was measured in terms of five categories namely physical adjustment factors, educational factors, health factors, social factors and financial factors. The expatriate's performance entailed a self-rating by the expatriate with reference to technical performance in the host location as well as integration and their ability to work effectively in cross cultural project teams.

\section{Research method}

\section{Research participants}

The target group consisted of expatriate employees working for a large multinational petrochemical company, who were either on an assignment for at least 12 months and typically up to three years or who had returned from an assignment in the previous 24 months. A pre requisite for inclusion was that the expatriate's spouse or partner had to accompany them. The sampling technique was convenience sampling, a technique considered appropriate for the study due to time limitations as well as the location and access to the sample population.

\section{Measuring instruments}

A survey was designed and comprised four main sections namely demographic variables, family adjustment, spillover and expatriate performance. Three measurement scales were used. Statements and closed questions were used in Sections Two, Three and Four. A combination of ordinal and nominal scales was used to collect data in respect of the demographic variables and a 5-point Likert type scale was used in Sections Two, Three and Five respectively. Provision was made at the end of the questionnaire for respondents to capture any additional comments about the family's experience whilst living in the host location and the impact this experience may have had on the expatriate's performance. Cronbach's reliability assessment confirmed reliability of the instrument.

\section{Research procedure}

The survey, a covering letter and participant instructions were distributed electronically by means of email to 153 respondents. Respondents were granted two weeks to complete the questionnaires. Reminders via email were sent after one week. After the second week, a further extension of one week was provided.

\section{Statistical analysis}

The Kaiser-Meyer-Olkin (KMO) measurement was used to establish whether factor analysis on the data would be useful followed by a factor analysis on 48 items on family adjustment, six items on spillover, and six items expatriate performance as reflected in Table 1 .

\section{Table 1: Factor analysis summary}

\begin{tabular}{|c|c|}
\hline $\begin{array}{c}\text { Physical } \\
\text { adjustment } \\
\text { factors }\end{array}$ & Initial adjustment items \\
\hline $\begin{array}{l}\text { Availability } \\
\text { and proximity } \\
\text { to public } \\
\text { amenities }\end{array}$ & $\begin{array}{l}\text { Availability of goods and services } \\
\text { Shops/malls } \\
\text { Proximity to shopping malls } \\
\text { The use of public transportation } \\
\text { Driving in the host location } \\
\text { Security at host accommodation } \\
\text { Proximity to the office } \\
\text { Proximity to schools }\end{array}$ \\
\hline Home comforts & $\begin{array}{l}\text { Parking facilities at host accommodation } \\
\text { Size of the accommodation } \\
\text { Size of the garden at host accommodation }\end{array}$ \\
\hline $\begin{array}{l}\text { Education } \\
\text { adjustment } \\
\text { factors }\end{array}$ & Initial adjustment items \\
\hline $\begin{array}{l}\text { Educational } \\
\text { support and } \\
\text { diversity }\end{array}$ & $\begin{array}{l}\text { Support of teachers } \\
\text { Multinational cultures } \\
\text { Making friends at school }\end{array}$ \\
\hline $\begin{array}{l}\text { Instructional } \\
\text { method, } \\
\text { curriculum } \\
\text { and peer } \\
\text { acceptance }\end{array}$ & $\begin{array}{l}\text { New curriculum } \\
\text { Different tuition language } \\
\text { Social demands by peers } \\
\text { Teaching styles }\end{array}$ \\
\hline $\begin{array}{c}\text { Health } \\
\text { adjustment } \\
\text { factors }\end{array}$ & Initial adjustment items \\
\hline $\begin{array}{l}\text { Medical } \\
\text { specialist } \\
\text { supplies and } \\
\text { services }\end{array}$ & $\begin{array}{l}\text { Pharmacist - availability } \\
\text { Pharmacist - services offered } \\
\text { Hospital - availability } \\
\text { Availability of medication } \\
\text { Hospital - services offered } \\
\text { Specialist - services offered } \\
\text { Specialists (e.g. cardiologist, gynaecologist, } \\
\text { physician etc.) - availability } \\
\text { Dentist - availability }\end{array}$ \\
\hline $\begin{array}{c}\text { Basic } \\
\text { healthcare }\end{array}$ & $\begin{array}{l}\text { General practitioner - availability } \\
\text { General practitioner - service offered } \\
\text { Dentist - service offered }\end{array}$ \\
\hline
\end{tabular}




\begin{tabular}{|c|c|}
\hline $\begin{array}{c}\text { Social } \\
\text { adjustment } \\
\text { factors }\end{array}$ & Initial adjustment items \\
\hline \multirow{6}{*}{$\begin{array}{c}\text { Social } \\
\text { Recreation }\end{array}$} & Use/availability of entertainment facilities \\
\hline & Distance to recreation and sporting facilities \\
\hline & $\begin{array}{l}\text { Distance to entertainment facilities (e.g. movies, } \\
\text { theatre, restaurants) }\end{array}$ \\
\hline & Internet/Skype connectivity \\
\hline & $\begin{array}{l}\text { Use/availability of recreation and sporting } \\
\text { facilities }\end{array}$ \\
\hline & Banking services \\
\hline \multirow{2}{*}{$\begin{array}{c}\text { Friends and } \\
\text { family } \\
\text { support } \\
\text { systems }\end{array}$} & Making friends with host country nationals \\
\hline & Missing support from family and friends at home \\
\hline \multirow{2}{*}{$\begin{array}{c}\text { Spiritual } \\
\text { affiliation }\end{array}$} & Place of worship \\
\hline & Distance to place of worship \\
\hline $\begin{array}{c}\text { Financial } \\
\text { adjustment } \\
\text { factors }\end{array}$ & Initial adjustment items \\
\hline \multirow{4}{*}{$\begin{array}{l}\text { Everyday } \\
\quad \text { living } \\
\text { expenses }\end{array}$} & Food \\
\hline & Entertainment \\
\hline & Domestic services \\
\hline & Accommodation \\
\hline \multirow{3}{*}{$\begin{array}{l}\text { Household } \\
\text { goods and } \\
\text { intermittent } \\
\text { expenses }\end{array}$} & Household goods \\
\hline & Clothing \\
\hline & Banking charges \\
\hline \multirow{3}{*}{$\begin{array}{c}\text { Public } \\
\text { services and } \\
\text { utilities }\end{array}$} & $\begin{array}{l}\text { Transportation (including fuel, public } \\
\text { transportation and vehicles) }\end{array}$ \\
\hline & Utilities including water \& electricity \\
\hline & School uniforms \\
\hline
\end{tabular}

\section{Results}

Significant relationships exist between the extracted factors relating to the family's adjustment dimensions. No significant relationship between adjustment factors and performance as well as between adjustment factors and spillover was found. However, the results indicated that performance is correlated with various adjustment items namely adjustment to making friends in school $(\mathrm{r}=0.402, \mathrm{p}$ $=0.025)$, multinational culture $(\mathrm{r}=0.410, \mathrm{p}=0.022)$, availability of hospitals $(\mathrm{r}=0.284, \mathrm{p}=0.011)$.

Spillover from home to work was confirmed:

- $82.72 \%$ of respondents confirmed that the respect they receive at home makes them feel more confident at work.

- $75.31 \%$ of respondents indicate that their family helps them to forget the pressure at work.

- $\quad 74.07 \%$ of respondents reported that their home life helps them relax and feel ready for the next day's work.

- $50 \%$ of respondents reported that they work longer hours than required in order to provide for their family. A large number of neutral responses for this statement are noted $(32.5 \%)$.

- $\quad 41.98 \%$ of respondents indicate that they often/very often talk with someone at home to help them deal with problems at work. This number represents the majority of respondents when taking into account the large number of neutral responses $(23.5 \%)$.

The Mann-Whitney $U$ test was used to investigate the differences between two independent groups on a continuous measure (refer to Table 2).

Table 2: Mann-Whitney $U$ test investigating differences between independent groups

\begin{tabular}{|c|c|c|c|c|c|c|}
\hline Group & Dimension & $\mathbf{N}$ & Mean rank & $\mathbf{Z}$ & $\mathbf{P}$ & $\mathbf{R}$ \\
\hline $\begin{array}{l}\text { Male } \\
\text { Female }\end{array}$ & Public services and utilities & $\begin{array}{r}72 \\
9\end{array}$ & $\begin{array}{r}43.13 \\
24.00\end{array}$ & -2.335 & .020 & 0.26 \\
\hline $\begin{array}{l}\text { Cross-cultural training } \\
\text { No cross-cultural training } \\
\end{array}$ & \multirow{2}{*}{$\begin{array}{l}\text { Household goods and } \\
\text { intermittent expenses }\end{array}$} & $\begin{array}{l}62 \\
19 \\
\end{array}$ & $\begin{array}{l}43.99 \\
31.24 \\
\end{array}$ & -2.084 & .037 & 0.23 \\
\hline $\begin{array}{l}\text { Received counselling } \\
\text { No counselling received }\end{array}$ & & $\begin{array}{l}19 \\
62 \\
\end{array}$ & $\begin{array}{l}52.24 \\
37.56 \\
\end{array}$ & -2.399 & .016 & 0.27 \\
\hline $\begin{array}{l}\text { Cross-cultural training } \\
\text { No cross-cultural training }\end{array}$ & Public services and utilities & $\begin{array}{l}62 \\
19\end{array}$ & $\begin{array}{l}45.05 \\
27.79\end{array}$ & -2.842 & .004 & 0.32 \\
\hline $\begin{array}{l}\text { Utilised relocation assistance } \\
\text { No relocation assistance utilized }\end{array}$ & $\begin{array}{l}\text { Sport, recreation and social } \\
\text { connectivity }\end{array}$ & $\begin{array}{l}54 \\
26\end{array}$ & $\begin{array}{l}44.02 \\
33.19 \\
\end{array}$ & -1.958 & .050 & 0.22 \\
\hline $\begin{array}{l}\text { HR consultation } \\
\text { No HR consultation }\end{array}$ & Spiritual affiliation & $\begin{array}{l}61 \\
19 \\
\end{array}$ & $\begin{array}{l}43.63 \\
30.45 \\
\end{array}$ & -2.202 & .028 & 0.25 \\
\hline $\begin{array}{l}\text { Married } \\
\text { Unmarried }\end{array}$ & \multirow{2}{*}{ Spillover } & $\begin{array}{r}73 \\
7 \\
\end{array}$ & $\begin{array}{l}42.57 \\
18.93 \\
\end{array}$ & -2.598 & .009 & 0.29 \\
\hline $\begin{array}{l}\text { First visit } \\
\text { More than one visit }\end{array}$ & & $\begin{array}{l}40 \\
40\end{array}$ & $\begin{array}{l}46.49 \\
34.51\end{array}$ & -2.328 & .020 & 0.26 \\
\hline $\begin{array}{l}\text { Utilised relocation assistance } \\
\text { No relocation assistance utilised }\end{array}$ & Performance & $\begin{array}{l}55 \\
26\end{array}$ & $\begin{array}{l}36.47 \\
50.58\end{array}$ & -2.543 & .011 & 0.28 \\
\hline
\end{tabular}


Table 2 indicates statistically significant differences between independent groups; findings related to performance and spillover will be discussed.

Spillover was rated higher by married respondents $(M d=$ 42.57, $n=73)$ than by unmarried respondents $(M d=18.93, n$ = 7), $U=104.500, z=-2.598, \mathrm{r}=0.29$, indicating the importance of spousal support, additionally spillover was rated higher by first time assignees $(M d=46.49, n=40)$ versus those who had been on more than one assignment $(M d$ $=34.51, n=40), U=560.500, z=-2.328, r=0.26$. This result could indicate that expatriates who have been on more than one assignment are more familiar with the uncertainty of an expatriate assignment than the first time assignees that may rely more heavily on the family for support.

Table 2 furthermore indicates a statistically significant difference between respondents who utilised relocation assistance and those who did not. Respondents who utilised relocation assistance $(M d=50.58, n=26)$, rated their performance higher than those who did not utilise relocation assistance $(M d=36.47, n=55) U=466.000, z=-2.543, r=$ 0.28 . This result could indicate that it is important for expatriates to be well adjusted increasing familiarity of the surroundings and reducing uncertainties allowing expatriates to focus on their performance.

The Kruskal-Wallis test was used to compare the scores on some continuous variable for three or more groups (refer to Table 3).

Table 3: Kruskal-Wallis test - Differences between performance, social recreation and length of stay

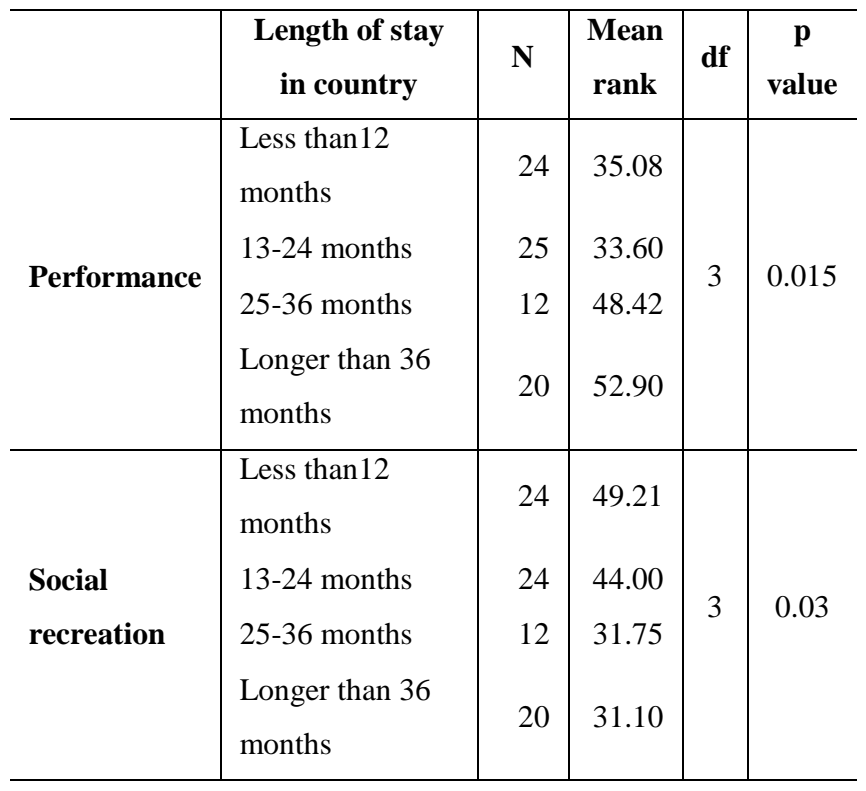

Table 3 indicates a statistically significant difference in performance ratings across four different durations i.e. length of stay in the host location (Gp 1, <12 months: $n=24, \mathrm{Gp} 2$, 13-24 months: $n=25$, Gp 3, 25-26 months: $n=12$, Gp 4, >36 months: $n=20), x^{2}(2, n=81)=10.500, p=0.15$. The group with the longest duration in a country (length of stay $>36$ ) recorded a higher median score $(M d=52.90)$ than the other three duration categories, which recorded median values as follows: $\mathrm{Gp} 1: M d=35.08, \mathrm{Gp} 2: M d=33.60, \mathrm{Gp} \mathrm{3:} M d=$ 48.42

Table 3 furthermore indicates a statistically significant difference in social recreation across four different durations i.e. length of stay in the host location. (Gp 1, <12 months: $n$ $=24, \mathrm{Gp} 2$, 13-24 months: $n=24$, Gp 3, 25-26 months: $n=$ 12, Gp 4 >36 months: $n=20), x^{2}(2, n=80)=8.947, p=$ 0.30 . The group with the shortest duration in country (length of stay $<12$ months) recorded a higher median score $(M d=$ 49.21) than the other three duration categories, which recorded median values as follows: Gp 2: $M d=44, \mathrm{Gp} 3: M d$ $=31.75, \mathrm{Gp} 4: M d=31.10$.

The results show that expatriates who had been in the country less than 12 months rated adjustment to social recreation higher, in other words more difficult to adjust to, than those who had been in the country for a longer period.

\section{Trustworthiness}

The internal reliability of the research questionnaire was measured and the Cronbach's alpha scores for all items relating to family adjustment are $>0.8$ except for the financial dimension (.742), indicating acceptable internal consistency. The study revealed Cronbach's Alpha values of 0.842, 0.837 , $0.940,0.878$ and 0.742 respectively for physical, educational, health, social and financial adjustment factors.

\section{Ethical considerations}

Based on the principle of conducting sound research and ensuring no harm, the purpose of the study was explained to the potential respondents. Participation was voluntary and each respondent was assured of the strictest level of confidentiality. All questionnaires returned to the researcher were treated with confidentiality.

\section{Discussion}

The main research objective is to identify the relationship between an expatriate's family's adjustment in the host country and the expatriate's performance. Secondary research objectives aim to establish the influence of home to work spillover on the expatriate's performance; and whether previous international assignments moderate the family's adjustment in subsequent assignments.

No significant relationship was found between the adjustment factors and expatriate performance. Length of stay was positively linked to expatriate performance as well as to social recreation. Spillover from home to work was confirmed. Strong correlations were found between the adjustment of expatriate children, and their own levels of performance as well as between their ability to adjust to the new culture, and their own levels of performance. The importance of organisational support was confirmed. 
A family's adjustment has the potential to affect expatriate performance (Chiotis-Leskowich, 2009), however in this study no correlation was found between adjustment factors and the expatriate's performance. However, respondents who had been in the host country for longer periods reported better performance ratings, thereby providing support for the UCurve adjustment theory (Black \& Mendenhall, 1991).

The findings indicate that the performance of the expatriate is influenced by whether or not the children are adjusted in the host location and whether they have friends or not. The importance of family adjustment, and specifically the children, is a vital aspect that requires additional focus and attention. A number of respondents indicated difficulty in adjusting to the new curriculum and teaching styles. Literature indicates that at least one in five partners or spouses reported that their children had problems adapting to new schools or making new friends, conversing and learning in a new language (Van Der Zee et al., 2007; Weeks, Weeks, \& Willis-Muller, 2010). The present study confirms that difficulty was experienced in adapting to new schools.

It is suggested that previous international experience forms part of the expatriate selection criteria (Aycan, 1997), furthermore where individuals have previous international experience, it is suggested that they will have a good idea of what to expect and hence this experience can be used to reduce uncertainty associated with future relocations and expatriate assignments (Louis, 1980). Comments from expatriates support this finding:

"A very easy transition for us. We had lived in the US before as a married couple, before joining the organisation. This move was like returning home."

"This was our third assignment and you learn to adapt to changing environments."

It is suggested that an individual's functioning at work may have a negative or positive impact on one's functioning and relationships at home. Similarly, one's functioning at home may also influence one's functioning at work in a positive or negative way (Byron, 2005). The results of the study indicated that positive spillover was experienced by the majority of expatriates.

Cross cultural training has been indicated as a critical success factor contributing to expatriate performance (Forster, 1997; Harrison, 1994). Organisational support utilised by expatiates and expatriate families prior to departure provides evidence that such support programmes for the family are essential to their adjustment, as it creates awareness of the host location which could facilitate adjustment.

The positive relationship between length of stay and expatriate performance, as well as evidence that support programmes are valued, indicates that endogenous factors, namely factors relating to business directly (e.g. length of time as an expatriate and organisational support) are stronger predictors of performance than exogenous factors, such as physical, education, health, social and financial factors. Ultimately, it can be concluded that support provided by the organisation is critical to successful family adjustment, ensuring a successful expatriate assignment.

\section{Practical implications}

This study adds value to expatriate management, considering the evidence that organisational support is not only necessary, but also valued by expatriates and their families, thereby facilitating their adjustment in the host location.

The family systems theory could be used as a model in preparing the family for the adjustment process, re-enforcing the principle that the family should function as a cohesive unit. Organisational support should be provided prior to departure, during the relocation and after the relocation. Many companies are good at providing support prior to and during departure, and then expatriates and their families are on their own. It is suggested that organisations review their support offerings at these three crucial times in the transition.

Furthermore, considering that $22.2 \%$ of respondents indicated difficulty in adjusting to the new curriculum and $18.5 \%$ indicated that teaching styles were challenging, the organisation could consider additional support to expatriate children in the form of, for example, paying for tutors, providing language lessons prior to leaving for the host country or additional online teaching support.

\section{Limitations of the study}

Expatriates were requested to rate their own performance, which could have been influenced by egocentric bias. It would have been preferable if the line manager was also requested to rate the performance of the expatriate and these compared to the rating awarded by the expatriate.

Similarly, the expatriate was requested to indicate the adjustment on behalf of the spouse and family; it would have been more suitable to have the partner or spouse and children where applicable, complete the separate sections relating to their own adjustment.

\section{Suggestions for future research}

Organisational support prior to departure for the expatriate and the family is valued and future research could investigate the effectiveness of organisational support both prior to and during the relocation. Further research can be done to empirically investigate in a triangular manner the impact of the family's adjustment in the host country on the performance of the expatriate from the perspective of the expatriate, the partner or spouse and accompanying children respectively.

\section{References}

Adler, N. \& Gundersen, A. 2007. International dimensions of organizational behavior. International dimensions of organizational behavior (5th ed.). Mason, OH: South Western College. 
Andreason, A.W. 2003. 'Direct and indirect forms of in-country support for expatriates and their families as a means of reducing premature returns and improving job performance', International Journal of Management, 20(4): 548-555.

Aycan, Z. 1997. 'Expatriate adjustment as a multifaceted phenomenon: Individual and organizational level predictors', International Journal of Human Resource Management, 8(August): 434-456.

Black, J. 1990. 'The relationship of personal characteristics with the adjustment of Japanese expatriate managers', Management International Review, 30(2): 119-134.

Black, J. \& Gregersen, H. 1991. 'The other half of the picture: Antecedents of spouse cross-cultural adjustment', Journal of International Business Studies, 22(3): 461-477.

Black, J. \& Mendenhall, M. 1991. 'The U-curve adjustment hypothesis revisited: A review and theoretical framework', Journal of International Business Studies, 22(2): 225-247.

Brookfield Global Relocation Services. 2011. Global relocation trends: 2011 Survey report. Business. Retrieved from http://www.brookfieldgrs.com/knowledge/grts_research/grts_medi a/2011_GRTS.pdf

Byron, K. 2005. 'A meta-analytic review of work-family conflict and its antecedents', Journal of Vocational Behavior, 67(2): 169198.

Carlson, D.S., Kacmar, K.M., Wayne, J.H. \& Grzywacz, J.G. 2006. 'Measuring the positive side of the work-family interface: Development and validation of a work-family enrichment scale', Journal of Vocational behaviour, 68: 131 - 164.

Carson, N.M. 2008. 'Talent retention and the international assignment', HR Perspective, 1(4): 14-17.

Che Rose, R., Sri Ramalu, S., Uli, J. \& Kuman, N. 2010. 'Expatriate performance in international assignments: The role of cultural intelligence as dynamic intercultural competency', International Journal of Business Management, 5(8): 76-85.

Chepkong'a, K. 2012. An exploration of the definition of expatriate failure and the predominant reasons for it. Expatriate failure research. Retrieved from http://businesseconomicreview. blogspot.com

Chew, J. 2004. 'Managing MNC expatriates through crises: A challenge for international human resource management', Research and Practice in Human Resource Management, 12(2): 1-30.

Chiotis-Leskowich, I. 2009. 'The family as a developmental issue in expatriate assignments', Development and Learning in Organizations, 23(6): 4-7.

Demerouti, E., Bakker, A.B. \& Tetrick, L.E. 2012. 'Regulatory focus and the family-work interface: The role of regulatory fit between cohabiting partners', European Journal of Work and Organizational Psychology, August(2012): 1-13.

ECA International. 2010. Managing mobility survey 2010. Managing. Retrieved from www.eca-international.com

ECA International. 2011. Expatriate salary management survey 2011. Management. Retrieved from www.eca-international.com
ECA International. 2013. National salary comparison. Retrieved from www.eca-international.com

Forster, N. 1997. 'The persistent myth of high expatriate failure rates: A reappraisal', International Journal of Human Resource Management, 8(August): 414-433.

Fukuda, J.K. \& Chu, P. 1994. 'Wrestling with expatriate family problems : Japanese experience in East Asia', International Studies of Management \& Organization, 24(3): 36-47.

Gabel-Shemueli, R. \& Dolan, S. 2011 'Do emotions matter? The role of emotional intelligence competences in cross-cultural adjustment for international assignment', Management Research, 9(3): 207-229.

Haar, J.M. \& Bardoel, E.A. 2008. 'Positive spillover from the workfamily interface: A study of Australian employees', Asia Pacific Journal of Human Resources, 46(3): 275-287.

Harrison, J.K. 1994. 'Developing successful expatriate managers : A framework for the structural design and strategic alignment of cross-cultural training programs', Human Resource Planning, 17(3).

Lazarova, M., Westman, M. \& Shaffer, M.A. 2010. 'Elucidating the positive side of the work-family interface on international assignments: A model of expatriate work and family performance', Academy of Management Review, 35(1): 93 - 117

Lee, H. 2007a. 'Factors that influence expatriate failure: An interview study', International Journal of Management, 24(3): 403413.

Lee, P. 2007b. 'Family support as a factor in cultural adjustment', Journal of Business Systems, Governance and Ethics, 2(2): 29-35.

Louis, M.R. 1980. 'Surprise and sense making: What newcomers experience in entering unfamiliar organizational settings', Administrative Science Quarterly, 25(June): 226-251.

Minuchin, S. 1974. Families and family therapy. Cambridge,MA: Harvard University Press.

Olson, D.H. 2000. 'Circumplex model of marital and family systems', Journal of Family Therapy, 22(2): 144-167.

Palthe, J. 2008. 'The role of interaction and general adjustment in expatriate attitudes: Evidence from a field study of global executives on assignment in South Korea, Japan and the Netherlands', Journal of Asia Business Studies, 3(1): 42-53.

Shi, L. \& Wang, L. 2014. 'The culture shock and cross-cultural adaptation of Chinese expatriates in international business contexts', International Business Research, 7(1): 23-33.

Shimada, K., Shimazu, A., Bakker, A.B., Demerouti, E. \& Kawakami, N. 2010. 'Work-family spillover among Japanese dualearner couples: A large community-based study', Journal of Occupational Health, 52(6): 335-43.

Srivastava, D.K. \& Panday, M. 2012. 'Dimensions of Indian expatriate adjustment in the USA: An exploratory study', Competitiveness Review: An International Business Journal, 22(4): $320-328$

Takeuchi, R., Yun, S. \& Tesluk, P.E. 2002. 'An examination of crossover and spillover effects of spousal and expatriate cross- 
cultural adjustment on expatriate outcomes', Journal of Applied Psychology, 87: 655- 666

Templer, K.J., Tay, C. \& Chandraskekar, N. 2006. 'Motivational cultural intelligence, realistic job preview, realistic living conditions preview and cross-cultural adjustment', Group \& Organisation Management, 31(1): 154-173.

Van Der Zee, K.I., Ali, A.J. \& Haaksma, I. 2007. 'Determinants of effective coping with cultural transition among expatriate children and adolescents', Anxiety, Stress, and Coping, 20(1): 25-45.

Weeks, K.P., Weeks, M. \& Willis-Muller, K. 2010. 'The adjustment of expatriate teenagers', Personnel Review, 39(1): 24-43.

Wilkinson, A. \& Singh, G. 2010. 'Managing stress in the expatriate family: A case study of the state department of the United States of America', Public Personnel Management, 39(2): 169-181.

Yuen, J. 2003. An exploration of the definition of expatriate failure and the predominant reasons for it. Retrieved from www.southerncross-group.org 